\title{
A Picomole-Scale Method for Rapid Peptide Sequencing Through Convenient and Efficient N-Terminal Phosphorylation and Electrospray Ionization Mass Spectrometry
}

\author{
Feng Wang, Hua Fu, Yuyang Jiang, and Yufen Zhao \\ Key Laboratory of Bioorganic Phosphorus Chemistry and Chemical Biology (Ministry of Education), \\ Department of Chemistry, Tsinghua University, Beijing, People's Republic of China
}

\begin{abstract}
Free or resin-bound peptides were phosphorylated at their $\mathrm{N}$-termini by reacting with dimethyl phosphite in the presence of tetrachloromethane and triethylamine, and some of them were labeled using partial deuterium-labeled dimethyl phosphites (molar ratio of $\mathrm{m}+$ 6 and $\mathrm{m}=1: 1$ or $\mathrm{m}+6, \mathrm{~m}+3$ and $\mathrm{m}=1: 2: 1)$ as the phosphorylating agents. The monophosphorylation of the lysine-containing peptides selectively occurred on the amino group of the N-terminus, not the side-chain of lysine residue. The resin-bound phosphoramidate peptides were cleaved by TFA before ESI-MS. The modified peptides were determined by electrospray ionization mass spectrometry, the protonated molecules of the unlabeled phosphoramidate peptides showed the singlet peaks, and those of the labeled phosphoramidate peptides displayed the doublet and/or triplet peaks. Tandem mass spectra (MS/MS) of the chosen protonated molecules gave sequential loss of the amino acid residues from the C-termini of the peptides, providing a convenient and rapid method for peptide sequencing. (J Am Soc Mass Spectrom 2006, 17, 995-999) (c) 2006 American Society for Mass Spectrometry
\end{abstract}

$\mathrm{R}$ apid and convenient peptide sequencing is highly desirable in proteomics and related bioscience. While the conventional method, Edman sequencing, does not fulfill this task, tandem mass spectrometry (MS/MS) provides a means for rapid identification and characterization of peptides/proteins [1-5]. Unfortunately, a protonated peptide is typically dissociated into a wide variety of N-terminal and Cterminal fragment ions. In general, it is difficult to predict which type of fragment ions will be formed for a single charged peptide, and the MS/MS spectra are often so complicated that de novo sequence determination is impossible. Many efforts have been made to enhance the response sensitivity and simplify mass spectra by modifying peptides. Positive [5-7] and negative [8] ion derivatization of peptides are two usual methods. In the previous research from our laboratory, it was found that the response sensitivity in positive ion FAB-MS [9] could be improved greatly by introducing a

\section{Published online June 6, 2006}

Address reprint requests to Dr. H. Fu, Laboratory of Bioorganic Phosphorus Chemistry and Chemical Biology (Ministry of Education), Department of Chemistry, Tsinghua University, Beijing 100084, People's Republic of China. E-mail: fuhua@mail.tsinghua.edu.cn

Also at the Key Laboratory of Chemical Biology (Guangdong Province), Graduate School of Shenzhen, Tsinghua University, Shenzhen 518057, People's Republic of China. neutral diisoproxyphosphoryl or diethoxyphosphoryl group to N-termini of peptides. The dissociation efficiency seemed to be higher in this case; unfortunately, a variety of dissociation pathways of the phosphoryl group complicated the mass spectra and sequence interpretation due to successive loss of two alkenes. In this paper, various free or resin-bound peptides were phosphorylated into phosphoramidate peptides using unlabeled and labeled dimethyl phosphites as phosphorylating agents, and the modified peptides were analyzed by ESI-MS, and tandem mass spectra (ESIMS/MS) of their protonated molecules showed unambiguously amino acid residue sequences of the original peptides.

\section{Experimental}

\section{Materials}

The Wang and Rink resin-bound protected peptides ( $10 \mathrm{mg}$ of peptides on $500 \mathrm{mg}$ of resin) were purchased from Glsynthesis Company (Shanghai, China). They are $\mathrm{H}-\mathrm{Val}-\mathrm{Glu}(\mathrm{OtBu})-\mathrm{Gln}(\mathrm{trt})$-His(trt)-Wang Resin (VEQH, loading $0.6 \mathrm{mmol} / \mathrm{g})$, H-Ala-Lys(Boc)-Asp (OtBu)-Leu-Wang Resin (AKDL, loading $0.6 \mathrm{mmol} / \mathrm{g}$ ), $\mathrm{H}-\mathrm{Val}-\mathrm{Tyr}(\mathrm{tBu})-\mathrm{Lys}(\mathrm{Boc})-\mathrm{Asp}(\mathrm{OtBu})$-His(trt)-Wang Resin (VYKDH, loading $0.56 \mathrm{mmol} / \mathrm{g}$ ), H-Ala-Arg(Pbf)-Leu- 


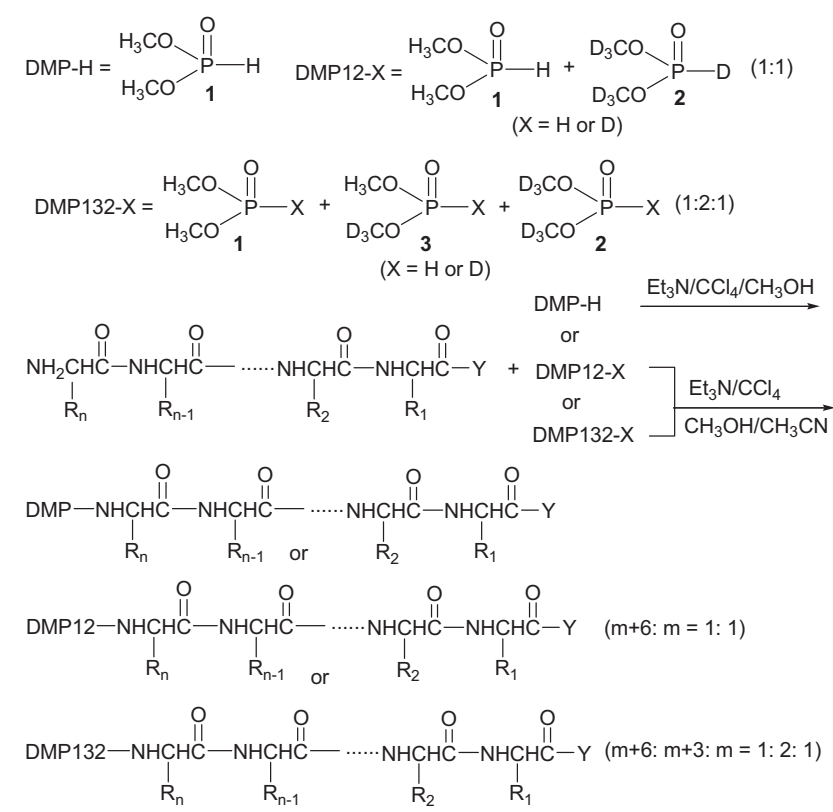

Scheme 1. Three phosphorylating reagents and the synthetic route for phosphoramidate peptides.

Val-Glu(OtBu)-Wang resin (ARLVE, loading $0.62 \mathrm{mmol} / \mathrm{g}$ ), H-Ala-Lys(Boc)-Asp(OtBu)-Trp(Boc)-Val-Rink Amide-AM Resin (AKDWV, loading $0.7 \mathrm{mmol} / \mathrm{g}$ ), and H-Leu-Pro-Asp$(\mathrm{OtBu})-\mathrm{Ser}(\mathrm{tBu})-\mathrm{Phe}-\mathrm{Ala}-$ Rink Amide-AM Resin (LPDSFA, loading $0.7 \mathrm{mmol} / \mathrm{g}$ ). Other chemicals were purchased from Aldrich (Shanghai, China).

\section{Synthesis of the Phosphorylating Reagents}

Dimethyl phosphite (DMP-H, 1), deuterium-labeling dimethyl phosphite $\left(\mathrm{D}_{6}-\mathrm{DMP}-\mathrm{D}, 2\right)$, and partial deuteriumlabeling dimethyl phosphite mixture (DMP132-X) (Scheme 1) were prepared according to the known procedure [10]. DMP12-X was obtained by mixing one equivalent each of dimethyl phosphite (DMP-H) and deuterium-labeling dimethyl phosphite ( $\mathrm{D}_{6}$-DMP-D). DMP132-X was prepared as follows: the mixed solution of methanol (24 mmol) and deuterium-labeling methanol $(24 \mathrm{mmol})$ in $5 \mathrm{~mL}$ of dry $\mathrm{CH}_{2} \mathrm{Cl}_{2}$ was added dropwise to $\mathrm{PCl}_{3}(8 \mathrm{mmol})$ in $5 \mathrm{~mL}$ of dry $\mathrm{CH}_{2} \mathrm{Cl}_{2}$ at $0{ }^{\circ} \mathrm{C}$ under nitrogen atmosphere. The solution was warmed to room temperature and stirred for $30 \mathrm{~min}$, and ${ }^{31} \mathrm{P}$ NMR spectroscopy showed that $\mathrm{PCl}_{3}$ almost quantitatively transferred into DMP132-X. The crude sample was obtained after distillation of gaseous $\mathrm{HCl}$ and $\mathrm{CH}_{2} \mathrm{Cl}_{2}$, and it was used without further purification $\left({ }^{1} \mathrm{H}\right.$ NMR showed that the purity was more than $98 \%) .{ }^{31} \mathrm{P}$ NMR of the three phosphorylating reagents: $\sim 12.5 \mathrm{ppm}$.

\section{Two Methods for Synthesis of Phosphoramidate Peptides}

Method A: $1 \mathrm{mg}$ of peptide-bound resin ( 2000 beads) was added to a $1.5 \mathrm{~mL}$ microcentrifuge tube, $100 \mu \mathrm{L}$ of trifluoroacetic acid (TFA) was added, and the peptide was cleaved from the Wang or Rink resin within $30 \mathrm{~min}$. TFA was removed with $\mathrm{N}_{2}$, and $10 \mu \mathrm{L}(72 \mu \mathrm{mol})$ of triethylamine, $20 \mu \mathrm{L}(0.21 \mathrm{mmol})$ of tetrachloromethane, $960 \mu \mathrm{L}$ of methanol and $10 \mu \mathrm{L}(\sim 90 \mu \mathrm{mol})$ of phosphorylating regent were added to the microcentrifuge tube containing the peptide at $0{ }^{\circ} \mathrm{C}$. The microcentrifuge tube was shaken for $2 \mathrm{~h}$ at this temperature, the tube was centrifuged, and $10 \mu \mathrm{L}(\sim 0.6 \mathrm{nmol} / \mu \mathrm{L})$ of the clear solution was drawn off and diluted with $990 \mu \mathrm{L}$ of methanol containing $0.05 \%$ TFA, and $40 \mu \mathrm{L}$ ( $\sim 6 \mathrm{pmol} /$ $\mu \mathrm{L}, \sim 240 \mathrm{pmol})$ of the resulting mixture was directly used to analyze by ESI mass spectrometry.

Method B: $1 \mathrm{mg}$ of bound-peptide resin was put to a $1.5 \mathrm{~mL}$ microcentrifuge tube, and then $100 \mu \mathrm{L}(720$ $\mu \mathrm{mol})$ of $\mathrm{Et}_{3} \mathrm{~N}, 100 \mu \mathrm{L}(1.04 \mathrm{mmol})$ of $\mathrm{CCl}_{4}, 400 \mu \mathrm{L}$ of methanol, $15 \mu \mathrm{L}(\sim 130 \mu \mathrm{mol})$ of phosphorylating regent were added to the microcentrifuge tube at $0{ }^{\circ} \mathrm{C}$. The tube was shaken for $4 \mathrm{~h}$ at this temperature, the solution was removed by filtration, and the peptidebound resin was washed with methanol $(3 \times 0.5 \mathrm{~mL})$. About 15 beads ( $\sim 4.5 \mathrm{nmol}$ of the modified peptide) were picked out and put to a $1.5 \mathrm{~mL}$ microcentrifuge tube, and $100 \mu \mathrm{L}$ of TFA was added to the tube. After 30 min, TFA was removed with $\mathrm{N}_{2}$, the residue was dissolved in $1 \mathrm{ml}$ of methanol containing $0.05 \%$ TFA, and $40 \mu \mathrm{L}(\sim 4.5 \mathrm{pmol} / \mu \mathrm{L}, \sim 180 \mathrm{pmol})$ of the solution containing the phosphoramidate peptide was peptide was analyzed by ESI mass spectrometry.

\section{Mass Spectrometric Conditions}

Electrospray ionization mass spectra were acquired on a Bruker ESQURE-LC ion trap spectrometer (Billerica, MA) equipped with a gas nebulizer probe. All experiments were carried out in the positive ionization mode. Nitrogen was used as drying gas with flow rate 4 or 8 $\mathrm{L} / \mathrm{min}$. The nebulizer pressure was 7 or $11 \mathrm{psi}$. The applied voltage on the electrospray needle was typically held at $4 \mathrm{kV}$ and the capillary temperature was maintained at $300^{\circ} \mathrm{C}$ for all samples. Forty $\mu \mathrm{L}$ of the phosphoramidate peptide solution was injected into the ESI source at a flow rate of $4 \mu \mathrm{L} / \mathrm{min}$. The number of overlap spectrum was 5 . Selected ions were analyzed by multistage tandem mass spectrometry using helium as collision gas.

\section{Results and Discussion}

\section{Preparation of Dimethyl Phosphite and the Phosphoramidate Peptides}

Reaction of $\mathrm{PCl}_{3}$ with three equivalents of $\mathrm{CH}_{3} \mathrm{OH}$ in $\mathrm{CH}_{2} \mathrm{Cl}_{2}$ gave dimethyl phosphite $(\mathbf{1}, \mathrm{DMP}-\mathrm{H})$, the corresponding deuterium-labeling dimethyl phosphite (2) was obtained when three equivalents of $\mathrm{CD}_{3} \mathrm{OD}$ was used instead of $\mathrm{CH}_{3} \mathrm{OH}$ in the reaction and a mixture of 1 and 2 (1:1) gave DMP12-X. Reaction of $\mathrm{PCl}_{3}$ with 1.5 equivalents of $\mathrm{CH}_{3} \mathrm{OH}$ and 1.5 equivalents of $\mathrm{CD}_{3} \mathrm{OD}$ 

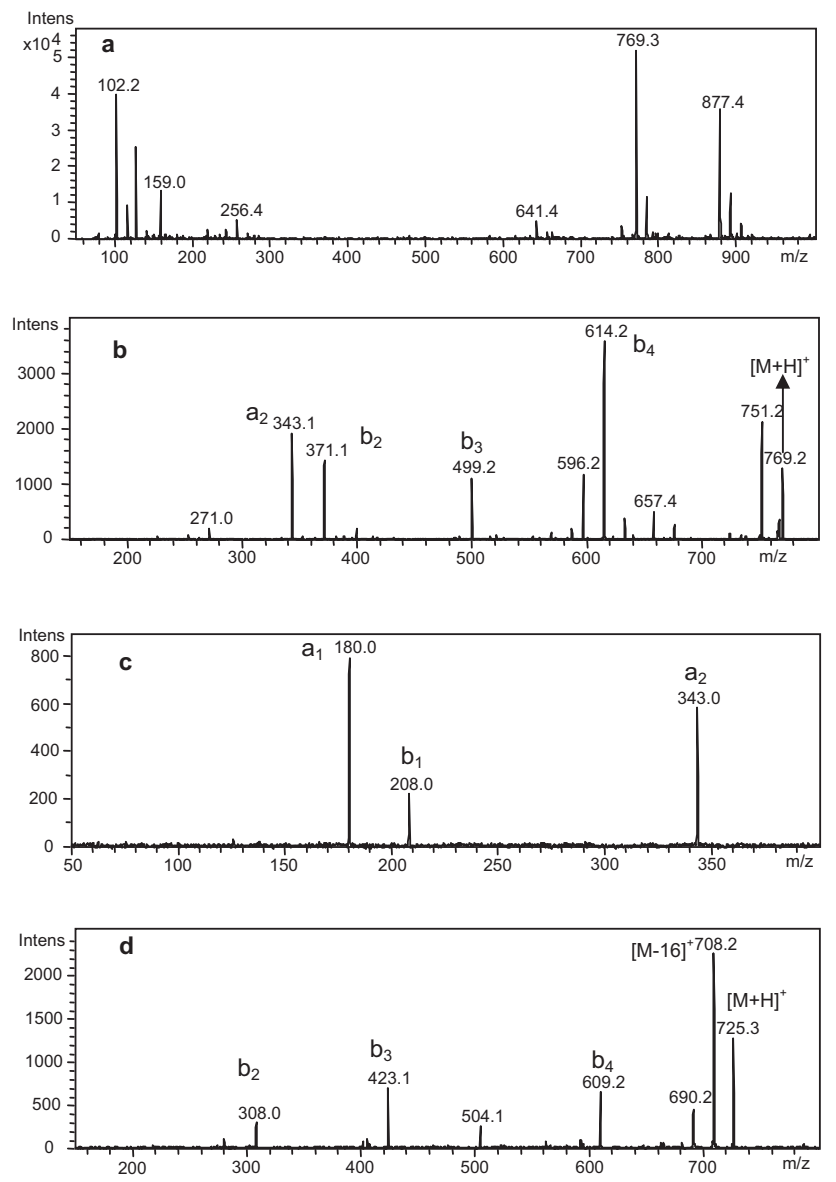

Figure 1. (a) ESI-MS spectrum of DMP-VYKDH-OH. (b) ESI-MS ${ }^{2}$ spectrum of the protonated molecule $[\mathrm{M}+\mathrm{H}]^{+}$at $\mathrm{m} / \mathrm{z} 769$ in Figure 1a. (c) ESI-MS ${ }^{3}$ spectrum of $\mathrm{a}_{2}$-ion at $\mathrm{m} / \mathrm{z} 343$ in Figure $1 \mathrm{~b}$. (d) ESI-MS ${ }^{2}$ spectrum of the protonated molecule $[\mathrm{M}+\mathrm{H}]^{+}$at $m / z$ 725 of DMP-AKDWV-NH $\mathrm{N}_{2}$.

yielded DMP132-X (Scheme 1). Reaction of the three reagents with peptides gave the corresponding phosphoramidate peptides.

\section{Phosphorylation of the Free Peptides and Peptide Sequencing}

Reaction mixtures obtained by method A (see the Experimental section) were analyzed directly. For example, the primary ESI-MS spectrum (Figure 1a) of phosphoramidate peptide DMP-VYKDH-OH cleaved from Wang-resin shows the protonated molecule $[\mathrm{M}+$ $\mathrm{H}^{+}$at $m / z 769$, the protonated diphosphorylated product at $m / z 877$ was also observed due to the presence of a Lys residue. The protonated monophosphorylated peptide at $m / z 769$ was selected for MS/MS analysis (Figure $1 \mathrm{~b})$. The $\mathrm{b}_{\mathrm{n}}$-type ions $(\mathrm{m} / \mathrm{z} 614,499,371)$ were observed together with $\mathrm{a}_{2}$-ion at $m / z 343$. ESI-MS ${ }^{3}$ of the $\mathrm{a}_{2}$-ion produced the $\mathrm{b}_{1}$-ion at $\mathrm{m} / \mathrm{z} 208$ (Figure 1c), allowing the phosphoramidate peptide to be easily sequenced as DMP-VYKDH-OH. Interestingly, the intense fragment ions in Figure $1 \mathrm{~b}$ all contain a phosphoryl group on the amino group of the $\mathrm{N}$-terminus and not the lysine side-chain, showing that monophosphorylation selectively occurred on the N-terminal amino group of the original peptide under the phosphorylating conditions described above. In fact, similar examples of selective $\mathrm{N}$-terminal modification for peptides containing lysine residue have been found using Spentafluorophenyl [tris(2,4,6-trimethoxyphenyl)phosphonium]acetate bromide [6] and 5-bromonicotinic acid N-hydroxysuccinimide ester [11] as the modifying reagents by Watson et al. and Tsunasawa and coworkers, respectively.

We also sequenced the phosphoramidate peptides containing a C-terminal amide group using a similar procedure. For example, the primary ESI-MS spectrum of DMP-AKDWV-NH $\mathrm{N}_{2}$ showed the protonated molecule $[\mathrm{M}+\mathrm{H}]^{+}$at $m / z 725$ and the protonated diphosphorylated peptide at $\mathrm{m} / \mathrm{z}$ 833.ESI-MS ${ }^{2}$ (Figure 1d) of the protonated molecule $[\mathrm{M}+\mathrm{H}]^{+}$at $m / z 725$ produced the $b_{\mathrm{n}}$-type ions at $m / z 609,423,308$, and ESI-MS ${ }^{3}$ of $\mathbf{b}_{2}$-ion at $m / z 308$ in Figure $1 d$ yielded the $b_{1}$-ion at $m / z$ 180. Therefore, the complete amino acid sequence of the phosphoramidate peptide was determined as DMPAKDWV-NH ${ }_{2}$. It was, however, difficult to identify quickly the protonated phosphoramidate peptides due to the presence of impurities in the spectra.

\section{Labeling of Free Peptides via Phosphorylation and Peptide Sequencing}

We overcame this problem with a labeling method involving phosphorylation of the free peptides with partial deuterium-labeled dimethyl phosphite (DMP12-X or DMP132-X) (Scheme 1). The protonated molecules of the monophosphorylated peptides showed doublet or triplet peaks due to isotopic labeling, and the diphosphorylated peptides on the amino groups of both the $\mathrm{N}$-terminus and side-chain of Lys residue displayed multiple peaks. The non-peptide impurities showed singlet peaks because they lacked amino group and could not be phosphorylated. For example, in the
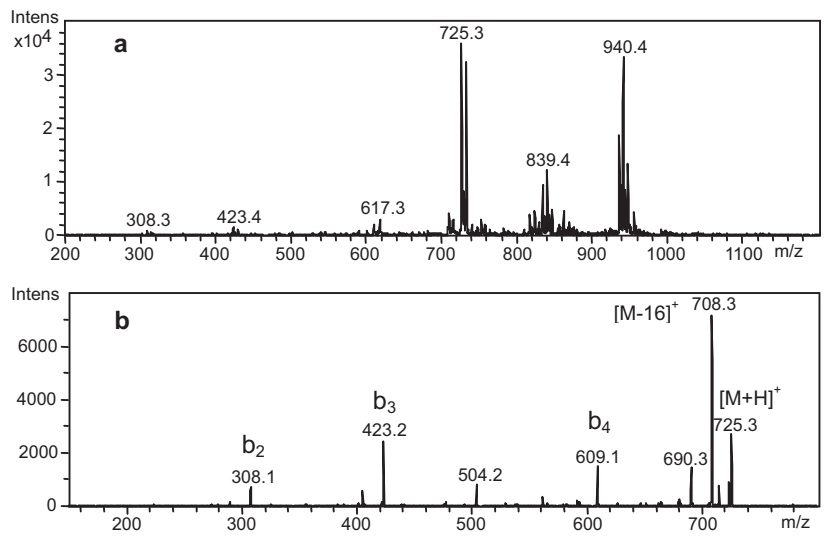

Figure 2. (a) ESI-MS spectrum of DMP12-AKDWV-NH $\mathrm{N}_{2}$. (b) ESI-MS ${ }^{2}$ spectrum of the protonated molecule $[\mathrm{M}+\mathrm{H}]^{+}$at $m / z 725$ in Figure 2a. 
spectrum of the phosphoramidate peptide DMP12-AKDWV-NH ${ }_{2}$, we could easily identify the double peaks at $\mathrm{m} / \mathrm{z} 725,731$ in Figure 2a corresponding to the protonated molecules of DMP12-AKDWV-NH ${ }_{2}$, ESI-MS $^{2}$ of the protonated molecule $[\mathrm{M}+\mathrm{H}]^{+}$at $m / z 725$ gave $\mathrm{b}_{4}$ $(m / z 609), b_{3}(m / z 423)$, and $b_{2}(m / z 308)$ ions (Figure $\left.2 b\right)$, and further fragmentation of the $b_{2}$-ion yielded the $\mathrm{b}_{1}$-ion at $\mathrm{m} / \mathrm{z} 180$. The results gave clear sequence information for the phosphoramidate peptide.

We also applied DMP132-X to phosphorylate peptides at their $\mathrm{N}$-termini. The protonated molecules of the monophosphorylated peptides showed triplet peaks, and the diphosphorylated products and impurity produced multiple and singlet peaks, respectively. In the case of a DMP132-AKDL-OH peptide, its primary ESI-MS spectrum (Figure 3a) shows triplet peaks corresponding to the protonated monophosphorylated molecules at $m / z$ 554, 557, and 560 (abundance ratio 1:2:1), multiple peaks near $\mathrm{m} / \mathrm{z} 668$ from diphosphorylated products, and some singlet peaks including $\mathrm{m} / \mathrm{z} 426$, 486, and 588 from impurities. The most intense triplet peak at $\mathrm{m} / \mathrm{z} 557$ yielded an ESI-MS ${ }^{2}$ spectrum (Figure $3 b)$ showing $\mathbf{b}_{\mathbf{n}}$-type ions at $m / z 436\left(\mathbf{b}_{3}\right), 311\left(\mathbf{b}_{2}\right)$ and $183\left(b_{1}\right)$, allowing straightforward assignment of the sequence.

\section{Phosphorylation of Resin-Bound Peptides and Peptide Sequencing}

The resin-bound peptides were also phosphorylated to give the corresponding phosphoramidate peptides using a similar procedure and then cleaved from the resin using TFA (Method B, in the Experimental section). Compared with the free peptides, the resin-bound peptides only provided monophosphorylated products because the $\varepsilon$-amino group on the lysine residue was protected. For example, the primary ESI-MS spectrum of DMP-VYKDH-OH showed the base peak at $m / z 769$ corresponding to the protonated molecule, and ESI-MS ${ }^{2}$ and $\mathrm{MS}^{3}$ spectra (similar to Figure $1 \mathrm{~b}$ and c) gave
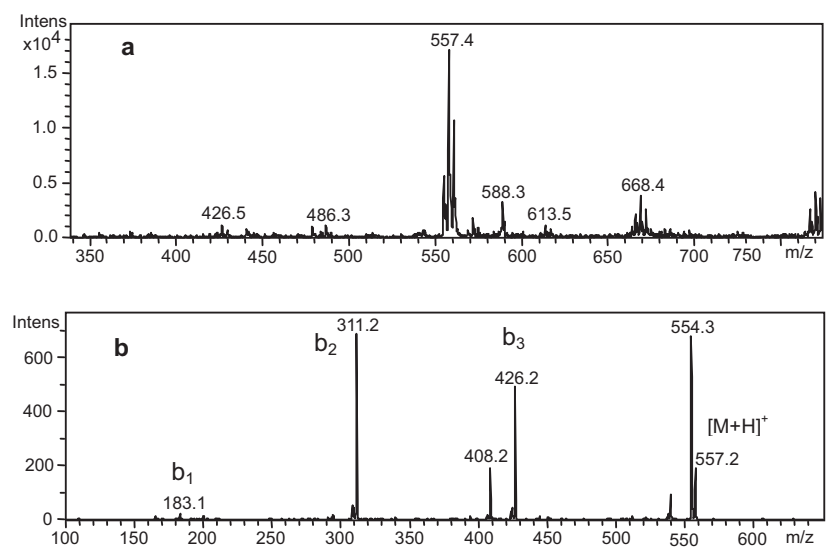

Figure 3. (a) ESI-MS spectrum of DMP132-AKDL-OH. (b) ESI$\mathrm{MS}^{2}$ spectrum of the protonated molecule $[\mathrm{M}+\mathrm{H}]^{+}$at $m / z 557$ in Figure $3 a$.

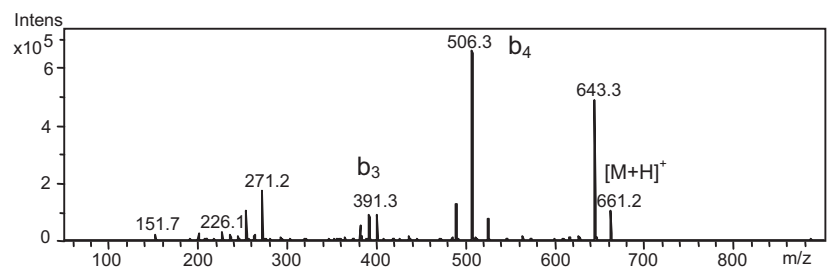

Figure 4. ESI-MS ${ }^{2}$ spectrum of the protonated molecule $[\mathrm{M}+$ $\mathrm{H}^{+}$at $m / z 661$ of VYKDH-OH

$\mathrm{b}_{\mathrm{n}}$-type ions at $m / z 614\left(\mathrm{~b}_{4}\right), 499\left(\mathrm{~b}_{3}\right), 371\left(\mathrm{~b}_{2}\right)$, and 208 $\left(b_{1}\right)$, providing the sequence of the phosphoramidate peptide.

\section{Labeling of Resin-Bound Peptides \\ Via Phosphorylation and Peptide Sequencing}

We used DMP12-X or DMP132-X to label the resinbound peptides through N-phosphorylation. The modified peptides were cleaved by TFA and then also unambiguously sequenced using similar procedures to those described above.

\section{Comparison of Unmodified Peptides and Phosphoramidate Peptides in ESI-MS}

We compared ESI-MS spectra of the unmodified peptides and the phosphoramidate peptides. Figure 4 shows the ESI-MS ${ }^{2}$ spectrum of the peptide VYKDH$\mathrm{OH}$. Compared with Figure 1b, Figure 4 exhibits a more complex spectrum, and only characteristic fragment ions $b_{4}$ and $b_{3}$ were observed. The N-terminal phosphorylating method selectively increased the intensities of $b_{n}$-type ions relative to other ion types, and the resulting simplified mass spectra clearly showed sequential loss of amino acid residues from the C-termini of peptides.

\section{Conclusions}

The peptides were phosphorylated into the corresponding phosphoramidate peptides, and the electrospray ionization tandem mass spectrometry of modified peptides provided clear sequence information on the original peptides. The protonated partial isotopicallylabeled molecules could be quickly identified in their primary mass spectra, which could reduce the consumption of sample during mass spectrometric analysis and improve the veracity of peptide sequencing. The present method has the following advantages: (1) a highly efficient and simple derivatization procedure; (2) selective N-terminal modification during monophosphorylation of peptides containing Lys residues; (3) selective fragmentation on the amide bond to form series of $b_{n}$-type ions, so it could be widely applied for peptide sequencing. 


\section{Acknowledgments}

This work was supported by the Excellent Dissertation Foundation of the Chinese Ministry of Education (no. 200222), Program for New Century Excellent Talents in University (NCET) in China, the Excellent Young Teacher Program of MOE, P. R. C., the National Natural Science Foundation of China (grant no. 20472042), and the Key Subject Foundation from Beijing Department of Education (XK100030514).

\section{References}

1. Roepstorff, P. Mass Spectrometry in Protein Studies from Genome to Function. Curr. Opin. Biotechnol. 1997, 8, 6-13.

2. Shevchenko, A.; Wilm, M.; Mann, M. Peptide Sequencing by Mass Spectrometry for Homology Searches and Cloning of Genes. J. Protein Chem. 1997, 16, 481-490.

3. Dongré, A. R.; Eng, J. K.; Yates, J. R. III. Emerging Tandem-MassSpectrometry Techniques for the Rapid Identification of Proteins. Trends Biotechnol. 1997, 15, 418-425.

4. Yates, J. R. III. Mass Spectrometry and the Age of the Proteome. J. Mass Spectrom. 1998, 33, 1-19.
5. Gu, C. G.; Tsaprailis, G.; Breci, L.; Wysocki, V. H. Selective Gas-Phase Cleavage at the Peptide Bond Terminal to Aspartic Acid in FixedCharge Derivatives of Asp-Containing Peptides. Anal. Chem. 2000, 72, 5804-5813.

6. Huang, Z. H.; Wu, J.; Roth, K. D. W.; Yang, Y.; Gage, D. A.; Watson, J. T. A Picomole-Scale Method for Charge Derivatization of Peptides for Sequence Analysis by Mass Spectrometry. Anal. Chem. 1997, 69, 137-144.

7. Keough, T.; Youngquist, R. S.; Lacey, M. P. A Method for HighSensitivity Peptide Sequencing Using Postsource Decay Matrix-Assisted Laser Desorption Ionization Mass Spectrometry. Proc. Natl. Acad. Sci. U.S.A. 1999, 96, 7131-7136.

8. Lindh, I.; Sjövall, J.; Bergman, T.; Griffiths, W. J. Negative-Ion Electrospray Tandem Mass Spectrometry of Peptides Derivatized with 4-Aminonaphthalenesulphonic Acid. J. Mass Spectrom. 1998, 33, 988-993.

9. Chai, W. G.; Yan, L.; Wang, G. H.; Liang, X. Y.; Zhao, Y. F.; Ji, G. J. Improvement in Sensitivity of Fast Atom Bombardment Mass Spectrometry of Amino Acids by Diisopropyl Phosphorylation. Biomed. Environ. Mass Spectrom. 1987, 14, 331-333.

10. Ji, G. J.; Xue, C. B.; Zeng, J. N.; Li, L. P.; Chai, W. G.; Zhao, Y. F. Synthesis of N-(Diisopropyloxy Phosphoryl) Amino Acids and Peptides. Synthesis 1988, 444-448.

11. Miyagi, M.; Nakao, M.; Nakazawa, T.; Kato, I.; Tsunasawa, S. A Novel Derivatization Method with 5-Bromonicotinic Acid N-Hydroxysuccinimide for Determination of the Amino acid Sequences of Peptides. Rapid Commun. Mass Spectrom. 1998, 12, 603-608. 